\title{
Rogue Neoliberalism, Liturgical Power, and the Search for a Left Governmentality
}

Dean, Mitchell

\author{
Document Version \\ Accepted author manuscript \\ Published in: \\ South Atlantic Quarterly \\ DOI: \\ $10.1215 / 00382876-7381170$ \\ Publication date: \\ 2019 \\ License \\ Unspecified
}

Citation for published version (APA):

Dean, M. (2019). Rogue Neoliberalism, Liturgical Power, and the Search for a Left Governmentality. South Atlantic Quarterly, 118(2), 325-342. https://doi.org/10.1215/00382876-7381170

Link to publication in CBS Research Portal

\section{General rights}

Copyright and moral rights for the publications made accessible in the public portal are retained by the authors and/or other copyright owners and it is a condition of accessing publications that users recognise and abide by the legal requirements associated with these rights.

\section{Take down policy}

If you believe that this document breaches copyright please contact us (research.lib@cbs.dk) providing details, and we will remove access to the work immediately and investigate your claim.

Download date: 26. Apr. 2023 


\section{Rogue Neoliberalism, Liturgical Power, and the Search for a Left Governmentality}

\section{Mitchell Dean}

Journal article (Accepted manuscript*)

\section{Please cite this article as:}

Dean, M. (2019). Rogue Neoliberalism, Liturgical Power, and the Search for a Left Governmentality. South At/antic Quarterly, 118(2), 325-342. https://doi.org/10.1215/00382876-7381170

DOl: https://doi.org/10.1215/00382876-7381170

* This version of the article has been accepted for publication and undergone full peer review but has not been through the copyediting, typesetting, pagination and proofreading process, which may lead to differences between this version and the publisher's final version AKA Version of Record.

Uploaded to CBS Research Portal: August २०२० 


\section{Rogue Neoliberalism, Liturgical Power, and the Search for a Left Governmentality}

\section{Mitchell Dean}

Our present is not lacking in novel and alarming characteristics and diagnoses: of a post-truth politics and the spread of fake news, of the dark arts of the internet, of populism as movement, politics and incompetent policy, of explicitly illiberal democracies and regimes, of collusions and meddling in democracies and their high politics, of anti-globalism, trade wars, and the making and remaking of state enemies such as Russia. It would be tempting to imagine that this present is a time like no other, a hinge moment of epochal significance, rather than a time just like any other in that it is like no other. Above all, it would be easy, and all too careless, to imagine that liberal democracies, and the neoliberalism that has played a major part in public governance for the last forty years, have made a sudden and unexpected authoritarian lurch.

What follows are two intertwined stories concerning neoliberalism and its authoritarian dimension. One is conceptual and theoretical and concerns a small domain of academic and intellectual activity: that of Michel Foucault, his influence in what has been called "governmentality studies" (Sennelart 2008: 390), and its status in a present in which there has been a belated rediscovery of the political. The second is the story of a different scale: of frameworks of governing and politics in contemporary liberal democracies, with a particularly emphasis on the extent to which that governing has been liberal, in the sense that it is a form of governing that operates primarily in relation to the freedom of the governed and only occasionally resorts to measures that are coercive or illiberal. At stake in the latter is the question of sovereign power, the nation, the state, the 
territory. For some time, we have been exercised with the irrationality of the rationalities of neoliberal government. Today we are forced to turn to the rationality of irrational neoliberal politics.

These stories are linked in that the former, concerning governmentality studies and their aftermath, has been one, influential way of understanding the latter, the actuality of forms of governing in contemporary liberal democracies. But it is also possible that the governmentality studies that proposed to study the rationalities by which rule takes place in these societies were not entirely immunized against features of such rationality and are thus hampered in their express aim to find a non-normative mode of analysis of rationalities and technologies of liberal, and neoliberal, government. My thesis is that the current conjuncture can be understood as a result of two contingent events: the failure of what Daniel Zamora (2017) has called the search for a "left governmentality"; and the transformation of the basis of legitimacy from rational public opinion fostered in the mass media to the evanescent and volatile fluctuations of public mood as revealed by social media, with a concomitant renewal of the public assembly (Dean 2017). Both public assembly and social media enact political liturgy or "liturgical power," as Nicholas Heron has called it (2018).

The story is told through three snapshots, or three "presents" as the Foucauldian critical historian would say: that of the late 1970s, when Foucault delivered his now famous lectures on the subject, but prior to neoliberalism entering the mainstream of public policy in liberal democracies; the high period of governmentality studies, and the period of the adoption of neoliberal technologies by labor and social-democratic parties of the 1980s and 1990s; and that of today, when Foucauldian perspectives have moved into full-blown scholasticism and academicism, but with a particular kind 
of legacy in the humanities and social sciences, and when multiple forms of neoliberalism persist despite the injury to their credibility of the previous decade's financial crisis and the rise of political movements - most often of the right - explicitly targeting its neglect, abandonment, and depredations.

This is a rogue neoliberalism, unanchored from the bases of its own legitimacy by financial crisis, inequality and rapacity, but somehow drawing upon a well of deep theological resources. In its wake, it has unmoored its own various "center-left," cosmopolitan, and globalist manifestations. It can reside both in the authoritarian resacralization of the market and national economy and the purification of the nation itself from foreign, ethnic and racial contaminants, and also in the libertarian "life-style politics" that claims to oppose it, and the pieties of the "rule of law" liberalism that seeks to keep it in check. In terms of cultural diagnostic and imagery, the Weberian "soulnessness" of the Fordist industrial welfare state has been replaced by a low-level confessional civil war between progressivist and fundamentalist neoliberalisms, from which the political left has largely absented itself. At the same time, a surplus of both political acclamation and capital accumulation is produced by social media companies, leading to a new kind of liturgical power that can be acted upon, manipulated and controlled with the same ruthlessness that an earlier generation of spin doctors sought to act upon the public opinion produced in the mass media. The manufacture of contempt has replaced the manufacture of consent.

\section{The Seventies: Coming Down}

In June 1975, Michel Foucault took LSD with two younger men at Zabriskie Point, Death Valley, California (Miller 1993: 245-84). At that time, and during the next few years, he would also experiment with the S/M practices of the clubs of San Francisco. While it would be purely 
speculative to draw a direct correlation between the test or "ordeal" (l'épreuve) of intense pleasures and the course of his work, the work that followed marked a much more affirmative attention to subjectivity, and to the political possibilities of radical self-creation and self-invention, than had been found in his earlier writings.

In these experiments with limits and transgression, with pleasure, truth and subjectivity, Foucault was certainly not alone. The mid-1970s were in many ways transitional years, from the more explicitly political collective actions, often with a revolutionary intent, that had followed May 1968 and the anti-Vietnam war protests, to a different kind of rebellion, concerned with self-stylization, with the assertion of the rights of groups engaged in such practices, and a movement away from what Foucault himself would have regarded as the old-style revolutionary project. Like similar challenges to the formal political spectrum, these cultural transformations had among their conditions the end of the postwar settlement and the Long Boom, the emergence of "stagflation," the resultant problematization of Keynesian macro-economic policy, and the reemergence of mass unemployment, particularly among the young.

At the same time, what would become the most influential political-intellectual movement, or “thought collective" (Mirowski and Plehwe 2009), was, not before conducting its own experiments in Latin America and particularly with the Pinochet regime in Chile (Fischer 2009), preparing to move out of the shadows and shape the policy prescriptions of liberal-democracies, the most exemplary, but not the only ones (witness New Zealand), being the Thatcher government in the United Kingdom and the Reagan administration in the United States. The explicit focus of this movement, a distributed network with a key node at the University of Chicago, was not the intensification of experience and the capacities for autonomous self-sculpture against the stifling 
normalization of the disciplinary state, but the limitation of the welfare state by various forms of market liberalization and the unleashing or extension of new kinds of freedom of choice. In this sense, while not becoming widely available for another two decades, Foucault's lectures on governmentality and liberalism in 1978 and 1979 are pivotal in that they lie at the intersection of this new concern for experimental self-creation with the recognition of the central significance of this emergent neoliberal movement.

Foucault (2008) framed neoliberalism within his idea of "governmentality" as a rationality of government, the latter understood as all the different ways in which human conduct would be tethered by various means (or "technologies") to specific ends with uncertain effectivity and results. Neoliberalism was not to be understood as the philosophy or ideology of the latest phase of capitalism but as the most recent iteration of a liberal art of government, that is, a critique, a method, or test (again, the keyword is l'épreuve) of how we are governed, of whether we are governing too much, of who or what is governing, especially the state (e.g. Foucault 2008: 317-25). Foucault focused on the statecraft embodied by neoliberalism rather than regarding it principally as a philosophy that somehow has implications for the form of governing by the state. Avant la lettre, he produced the first account of neoliberalism as a thought collective, and in particular offered his audience expositions of the nature of and differences between German Ordoliberalism and American Chicago School neoliberalism.

Whatever we think of the as yet unresolved controversy of Foucault's own relation to neoliberalism (Zamora and Behrent 2016), his perspicacious analysis of it draws out several themes that are relevant to our understanding of the relation between neoliberalism and a supposed authoritarian turn. First, Foucault notes that neoliberalism seeks to actively construct forms of freedom rather 
than assume it to be a natural feature of unconstrained individuals pursuing their interests in the market, as it had in more classical forms of economic liberalism such as that of Adam Smith. Secondly, the market itself is de-naturalized, so that its construction becomes the principle of legitimation of the state, and only so under definite legal and political conditions, as in the Ordoliberals, or a technique by which formerly public services and policy domains could be reconstructed, e.g. drug policy or the entire field of crime and justice, as in the Chicago School. Neoliberalism is less a rollback of the state, although at times it takes on such a character, and more a mode of "veridiction" (truth-telling) for an art of government (Foucault 2008: 32). Government is not simply reduced to a market or economic rationality but it enters into a tête à tête with it. The market is a form of the manifestation of truth, and special authority thus goes to its truth-tellers, the economists.

Thirdly, neoliberalism for Foucault presents a new understanding of subjectivity. Unlike the disciplinary and biopolitical forms of power he had earlier analyzed, it no longer sought to "make up people" through the normalizing techniques of the human sciences. Previous health, welfare and education systems sought to produce particular kinds of subject. Domination had not proceeded by the objectification of what was truly human, as the Frankfurt School had contended, but by the creation of a certain kind of subject, docile, useful, and self-responsible. Social work, criminal anthropology, and child psychology, among the other disciplines of the human sciences, had conspired in the production of the "modern soul." Neoliberalism, in direct contrast, would move to the side of the subject and its choices and seek to govern conduct not by the oppressive imposition of subjectivities (the criminal, the recidivist, the homosexual, the underclass, etc.) but by acting on the conditions of choice, with the minimal supposition that choice was simply a "non-random" phenomenon. It would proceed by changing the rules of the game rather than supervening upon the 
individual. Neoliberalism didn't so much aim to produce subjects as to cultivate desirable attributes of enterprise and competition by acting on the environment of individuals and their field of choice.

In this respect for Foucault, neoliberalism, at least as an ideal or a political imaginary, marked a rupture with earlier forms of power that he had analyzed and which had come to be embodied in the institutional and juridical structures of the modern welfare state. It was, at least in its utopian manifestation, a way of governing that tolerated differences and was open to diversity, that offered support to the emerging minority groups who sought to maximize autonomy in their own selfdefinition and self-creation and resist the subjection of the welfare state and human sciences.

This is not to say that Foucault saw no dangers in neoliberalism, chief among them being the manipulation of choice by environmental interventions, but these should be weighed up against the considerable potentials he finds in it. However, in expressing the view that the Left would have to draw from liberalism to constitute an art of government, and that there was no equivalent in the socialist political canon, Foucault set the course for what might be called the search for a left governmentality. At the same time, the most famous names of the neoliberal thought collective were enunciating the principles of neoliberalism's relation to authoritarianism in the context of their involvement in the Pincohet regime. Friedrich Hayek (1981) seemed to surprise himself in an interview in Santiago when he found himself preferring a "liberal dictator" to a "democracy lacking liberalism," and arguing that sometimes "democracy needs the broom of strong government." More concisely, for neoliberals such as Hayek and Milton Friedman, liberalism and democracy were not the same thing and that the opposite of liberalism was not authoritarianism but totalitarianism, and authoritarianism could thereby serve true liberalism. Rather than a recent authoritarian turn, neoliberalism as an intellectual and political project was prepared to sacrifice, at least temporarily, 
democratic procedures and rights for an authoritarian state willing to implement the conditions for a "free market." In this respect, it had learnt the lessons of a "commissarial dictatorship" that Carl Schmitt (2014) had identified just after World War I.

\section{Searching for a Left Governmentality}

By early 1990s neoliberalism had become a dominant project of public governance in the Anglophone world and certainly a vigorous challenger to the previous "path dependencies" (Brenner, Peck and Theodore 2009) of the Nordic social-democratic welfare states and Western European forms of corporatism, and was exported or welcomed in many parts of the world from Latin America to the former Soviet Union. After the first decade of forms of neoliberalism with emphasis on the mechanisms of the rollback of the state through privatizations of state organizations, fiscal austerity, anti-inflationary monetary policies, the Left or what styled itself as the "center-Left" began to look to find what lessons it could learn from neoliberalism. By the mid1990s, it was labor and social-democratic parties, at least in the Anglophone world, and international organizations such as the Organization for Economic Cooperation and Development (OECD), that would be instrumental in carrying through a thorough-going reform of institutions and institutional practices, particularly in regard to welfare, social security, health care and education, according to principles of competition and enterprise, and through techniques of the recomposition of the public sector (under the "new public management") so that it would act more and more like a series of "quasi" or constructed markets. "Precarity" was now a firmly entrenched feature of liberal democracies, and the occasion for ever-new cultural problematizations and "culture wars," and demands for the reformation of governmental practices under the newspeak term "welfare reform." This was a term especially associated with the Clinton-era Personal 
Responsibility and Work Opportunity Reconciliation Act of 1996 and with the new welfare discourse more generally (Schram 2000).

Foucault's lectures on neoliberalism had ended a month before the signal election of the Thatcher government in the UK. In them, Foucault (2008: 92, 100n) had argued that there was no autonomous socialist governmentality, and had promised to deliver a book on the socialist arts of government. He had made two points that are salient here both to the course of social theory and philosophy and to the search for a left governmentality. First, while there was no autonomous socialist governmentality, it could and, in its historical forms, did borrow from other forms of governmentality. While the socialism of the Communist Parties had borrowed from the governmental techniques of the police state and tied itself to a "governmentality of the party" (Foucault 2008: 90-92, 191), the post-war German Social Democrats, after the Bad Godesburg congress of 1959, had effectively abandoned socialist precepts and Marxist theory and embraced the consensus of a liberal governmentality associated with the Ordoliberals. Foucault seemed to suggest a version of Mrs Thatcher's TINA (There Is No Alternative) principle: leftist and socialist parties would be forced to decide on the art of government available to them and that choice would be between the dark arts of totalitarianism and the light techniques of economic liberalism.

The second point concerned the shift of the focus of politics from a question of exploitation to ones of subjectivity and the implications of this for public policy. For Foucault as we have seen, American neoliberalism, at least as an ideal program, works through constructing choice, not through the production of subjectivity as did the pastoral-inspired welfare state (Foucault 2008: 259-60). This difference is also played out on the register of practical policies. Criminal justice will not be organized according to the truth of various forms of subjectivity but according to the 
"negative demand" for crime and the calibration of the risks of the individual subject considered not as a criminal, but as a rational subject of choice (Foucault 2008: 255). In proposals for a negative tax under Giscard d'Estaing, the question of the unemployed person is no longer one for disciplinary, bureaucratic, or inquisitorial practice but of the choices of the individual in a game of competition. It is up to the individual whether they want to work or not, in the knowledge that they will be sure of a minimal subsistence, saved from absolute but not relative poverty (Foucault 2008: 205-7).

In an interview with the chief of a centrist trade union, Foucault began to sketch out what this left governmentality would look like. The problem of the welfare state has always been one of the trade-off between security and autonomy, but now its pathology is not simply the possibility of marginalization from society but also the integration into the mechanisms of social security themselves and the resulting dependency that entails (Foucault 1988: 160-5). Foucault thus suggests it is necessary to defer to what he calls the "political, economic and political rationality of modern societies," namely the policy prescriptions he learnt about in his analysis of neoliberalism. Such a rationality chimes with his answers to these problems framed in terms of a "way of life" and "lifestyles." In keeping with the social movements of everyday resistance to institutional, disciplinary and patriarchal power, he notes that rationality demands a "security that opens the way to richer, more numerous, more diverse, and more flexible relations with oneself and one's environment, while guaranteeing to each individual a real autonomy" (Foucault 1988: 161). To combat welfare dependency, Foucault suggests "a process of decentralization" that would lead to a closer relation between users of services and "decision-making centers" (1988: 165). In short, the structural economic problems of the fiscal crisis of the welfare state of his time were to be met by the serendipitous conjunction of the need for a decomposition of the social state with the new 
approaches to subjectivity made possible in recent struggles. In fact, Foucault concludes, the welfare system should become a "vast experimental field" and the "whole institutional complex, at present very fragile, will probably have to undergo a restructuring from top to bottom" (1988: 165, 166). Just as the subject would remake itself through intense ordeals and the forms of truth they engender, the entire welfare state would be put to the test in relation to the regime of veridiction of the market.

By the 1990s the restructuring of the welfare state from top to bottom was a real and pressing concern. The idea of social rights of individuals was displaced by the mutual obligation of individuals and government, in which government would ensure, but did not necessarily provide, the delivery of some kind of social provision, in exchange for social beneficiaries remaking themselves in particular ways, learning to plan their own lives, combatting the ill-effects of their risk of welfare dependence, undertaking training and retraining as required, undergoing therapy and being case-managed, and learning to act more and more like an enterprise. Key themes would include the telos of an "active society," with flexible and agile populations, able to take the changing opportunities of the market, now projected onto a global scale rather than remaining at a national one, made competitive by the investments in human capital and the enterprise of the individuals that composed it (Dean 1995). As Foucault foreshadowed, the individual, having been through all a series of tests and ordeals, would experience the pleasures of life as an enterprise.

While Foucault would look to Greco-Roman antiquity for an autonomous practice or care of the self, other theorists of left governmentality would find an easier route through the sociological supposition of changing forms of subjectivity. While not using such an expression, sociological theorists, such as Ulrich Beck (1992) and Anthony Giddens (1991), would argue that under 
conditions of late modernity, the individual would no longer be bound by the ascribed characteristics of class, race and ethnicity, gender and sexuality, that had been transmitted by traditional, patriarchal, familial and religious forms of socialization. Rather individuals were capable of remaking themselves, with or without the help of the armies of therapists and self-help experts, of examining the contents of their given identities, including those of class, of challenging them and making new choices for themselves. The individual would be capable of narrating and renarrating their own lives, choosing their own personal and sexual identity, and entering into intimate relations on a new ground of equality rather than conventional patriarchal and traditional hierarchical relations. This "reflexive project of the self" would at best lead to a new "cosmopolitan" identity that would be capable of understanding and empathizing with the trajectory of other very diverse pathways to this reflexive identity. As class identities and solidarities loosen and lose their defining significance for identity, the presence and impact of a class politics of mass labor parties and trade unions would diminish and eventually disappear. The reflexive, self-making individuals would identify with multiple and different communities and forms of political associations around these new identifications. The importance of the autonomy, vibrancy and vitality of civil society or community would be rediscovered. It would be the place of the experimentations made possible by these new diverse collective identifications and would also become the means by which the fiscal problems and bureaucratic sclerosis of the welfare state would be attenuated, if not fully solved, and on a global scale, problems of war, poverty and the environment, would be addressed.

The diagnostic moment for such social theory comes when we turn to public policy. Because the truth of the subject was changing, and the potential of a new self-making or reflexive individual was emerging in "second modernity," it was no longer possible to provide governmental programs and 
politics around the old solidarities of class and family. Rather than being the recipient of a right, the individual had to become a certain type of subject, with the help of a range of experts, but no longer under their tutelage and as a full and equal partner; the vertical relations of state, authority and expertise were to be replaced by horizontal and reciprocal ones that enlist the subject's own capacities, lifestyle, and forms of freedom in the process. Life had become a "planning project." As Giddens (1998: 36-37) put it: "We have to make our lives in a more active way than was true of previous generations, and we need more actively to accept responsibility for the consequences of what we do and the life habits we adopt." Or, even more bluntly, this from Ulrich Beck (1992: 135): "In the individualised society, the individual must learn, on pain of permanent disadvantage, to conceive of himself of herself as the centre of activity, as the planning office with respect to his or her own biography, abilities, orientations, relationships and so on." Such was the universal lesson of this new modernity for rich and poor, S/M-experimenting philosophers and dope-smoking unemployed youth, Cambridge white male academics and black teenage moms, alike. Cuius societas, eius forma vitae.

There is then a direct link between sociological theories of the self and the individualization processes of late modernity and the programs of government that seek to elicit such selftransformational capacities from the individual. This is the key lesson of the Third Way politics in which Anthony - later Lord - Giddens would play the crown theorist to Tony Blair's New Labour. But the aporias of turning a general sociological theory of the subject into a normative governmental one soon would multiply, but with devastating consequences for those who would meet the newly privatized, marketized and individualized service provision amidst the ruins of the welfare state. One can note that the categorization of individuals according to such individualizing capacities leads to a particular hierarchy in terms of the degree of capability of exercising 
autonomy, and the emergence of multiple categories of those "at high risk of welfare dependency," who should be subject to a range of educational and training, and therapeutic, practices to assist in the gaining of such capabilities. Because they do not have or have yet to develop such capacities, they need to be encouraged, enticed and even forced into such: hence the long deliberation on and experimentation with the relationship between libertarianism and paternalism, first with the New Paternalism and latter with the advocacy of a libertarian paternalism and nudge theory. If neoliberal policy prescriptions had been revealed to be entirely compatible with the authoritarian and dictatorial regimes at national levels during the 1970s and, in many instances, required them, by the 1990s it was becoming clear that the neoliberal prescriptions for the shaping of choice and freedom were necessarily connected with the instantiation of systems of obligation and coupled with more or less disciplinary, coercive and sovereign instruments. Amongst the coercive ones would be the widespread use of workfare programs (Peck 1998), that is, make-work programs which simulated employment for social welfare beneficiaries and made participation in them conditional upon receiving of benefits. The limits of the governmentality of the welfare recipient are revealed by the increasing use of the removal of benefits from the individual for failing to participate in said programs or to make enough job applications, and the mandating of what benefits can be spent on. The net effect of this conditionality is the deterrence of the use of social welfare by large sections of the population leaving them to the vagaries of the precarious and minimum-wage employment market, "zero-hour" contracts, the "gig economy," the support of their families and friends, the empty promises of entrepreneurship and start-ups, or, worse still, grifting and less socially acceptable ways of eking out a living. There is little choice between the ordeals required to remake oneself as an enterprise and the quotidian ordeals of a deconstructed labor market. The neoliberal celebration of identity and self-making is mired in the authoritarian practices it generates (Dean 2002). 


\section{Confessional Civil War}

The cultural diagnosis of the Fordist industrial welfare state was one of Max Weber's "iron cage" in which the individual was reduced to the compulsory pursuit of a career, or at least performance of a job, within the industrial and bureaucratic divisions of labor of large corporations and government departments. The fate of modernity appeared to be one of soulnessness and alienation. Recently, in Europe and the United States, another trope has appeared: that of civil war. Emmanuel Macron, president of France, has used the term to describe the relationship between the European Union and the self-proclaimed "illiberal democracies" such as Viktor Orban's Hungary and those following in their wake (Erlanger 2018). Many commentators in the United States have taken up the theme of civil war. In one instance, it describes for the relation between an unpredictable authoritarian decisionism of the Trump administration that undermines the "rule of law" and the legal protection of the autonomy of the states of the Union (Greenhouse 2018). In this way, the cultural-political diagnostic of the present seems much closer to Carl Schmitt's writings in the Weimar republic, than to that of the Protestant Ethic, as a continuation of confessional civil war by other means (Ulmen 1985). Indeed, after the full flush of the alignment between liberalism and cosmopolitan globalism of the 1990s, we have witnessed the re-emergence of deadly antagonisms taking several forms: from the civilizational ones of Samuel Huntington, to the discovery of non-state enemies of humanity of the War on Terror and the neo-conservatives at the time of George W. Bush's administration, and the revival of state enemies such as Russia largely by progressive liberals and the mass media. Today, to refine the image, these antagonisms take the form of a kind of lowintensity confessional civil war within liberal-democracies themselves. 
On occasion, the latter manifests itself in the speeches of politicians during the hurly burly of political campaigns. In the United States, a finance-friendly progressivist neoliberalism has fought the alliance of a literally armed white working-class with Christian fundamentalists and evangelicals. Before Hilary Clinton's characterization at a "LGBTQ gala" fundraiser of half of Trump's supporters as being in "a basket of deplorables" who are also, with a more theologically resonant accent, "irredeemable," there was then Senator Obama's 2008 view of the white workingclass who, due to economic hardship, had become bitter and "cling to guns and religion" (Chozick 2016). In Europe during the debt crisis, the confessional civil war takes place between the Protestant North-West and its institutions such as the Ordoliberal-inspired European Union, the European Central Bank and the German government and its Finance Ministry, and the Orthodox and Catholic South and East, who, according to the former, would lack the "solidity" of character and the regularized and self-responsible life-conduct required for necessary European "solidarity" (Hien 2017).

One does not have to accede to Macron's diagnosis to grant that civil war acts as an effective political imaginary in the present. From his perspective, there is an identity between liberalism and democracy, making both an illiberal democracy and a despotic liberalism contradictions in terms. It thus suppresses the different scales of the relationship between neoliberal rule and authoritarianism: whether concerning the regimes of the government of national states and the international order or of the techniques of management of various populations and individuals, as we have seen above. On the other hand, this perspective fails to recognize how much of the neoliberal political and policy agenda is being implemented by that which it posits as its opposite. Rather than two opposed ideologies and contrasting worldviews, such as the Cold War binary between Communism and Capitalism, progressive, financial neoliberalism finds a distorted version of itself in its Other. The 
nativist expulsion from the body of the nation of undesirable populations is tightly coupled with the expulsion from the market of unnecessary regulation. Populism clings like mud shaped by neoliberalism's anti-statist and anti-bureaucracy tire tracks: from the "drain the swamp" variety in the United States to Matteo Salvini's (of the Italian party of government, the League) characterization of his prime ministerial designate as an "expert in simplification and debureaucratization" (Horowitz 2018).

So, what has happened? Neoliberalism as a thought collective and path dependency has largely succeeded in the economic "neutralization" of the political. The failure of the search for a left governmentality, or the adoption by "center-left" parties of neoliberal technologies of government, together with a widespread intellectual anti-statism and rejection of formal politics, has deprived or at least undermined labor and social-democratic parties' organic concerns with the conditions of the working and precarious populations, leaving little effective voice of discontent other than antiglobalist appeals to a "walled sovereignty" (Brown 2010). Instead, as exemplified by the Clinton campaign in 2016, the "center-left" becomes - or at least can be readily portrayed as by its opponents - the party of diversity disconnected from fundamental concerns around economic exploitation, widening inequality and narrowing life-chances for a sizable segment of its traditional constituents. This means that there is an opportunity to articulate economic grievance and disappointment with an attack on cultural as well as economic "elites" of contemporary capitalism. It is also possible to articulate a possible identity politics for those left out of it. Thus, groups that include many who would be conventionally defined through ascribed characteristics as white, male, and working class, demand to be heard not in terms of their class position but as yet another identity group with specific interests, needs and rights. Isn't gun-owning simply another life-style for rural 
people? In an age where sexual minorities are encouraged to assert their rights, what about the ordeals of involuntarily celibate men, as the "incels" violently assert?

At the same time, the kind of developments that undermined the Fordist system of industrial production, and the welfare state, have utterly transformed the previous hegemony of the capitalist media corporations and the form of public sphere and public narratives they sustained. Social media, and the forms of participation it has engendered, not only multiply sources of knowledge and opinion and increased opportunities for political participation and identification, but unravel the regimes of truth characteristic of the mass media (Dean 2017). The "objective" voice of the narration formed through the mass media is displaced by the more volatile swings of the public mood registered and almost immediately legible on social media, and the tribal truths of those who make specific identifications through social media. The latter, of course, becomes a new domain of political manipulation and control, much to the surprise of the peddlers of liberal teleologies of the progressive expansion of civil society. Yet the relations of power and possibilities of manipulation run much deeper than the "surveillance society" with its increased digital panopticism and even "algorithmic governmentality" can allow. While there is much talk of a "politics of untruth" or of "post-truth politics," we can say that the mass media, like science, has lost its monopoly on truth. Indeed, the demand for regulation of social media in the name of individual privacy, and the protests in the defense of science, can be understood as belated and parallel attempts by the mass media and institutionalized science to reclaim their monopolies on certain manifestations of truth. What is paradoxical is those who once might have criticized the first as purveyors of ideology and the other as reductionist and positivist, can now find themselves aligned with both. 
When the alt-right emerged as an actor in the 2016 US election it may have appeared as little more than white supremacism mixed with wounded masculine aggression (Green 2017). However, at least publicly, it succeeded in representing itself as a conjunction of social media savvy with the appropriation of identity politics on behalf of the "forgotten" populations laid waste by global capitalist competition and the deconstructed welfare state. It demonstrates the capacity to extend the political manipulation of the public sphere from the dispositive of public opinion associated with the mass media to the dispositive of the "public mood" formed through social media (Dean 2017). While it is easy, and somewhat facile, to regard this latter shift as a seismic catastrophe for liberal democracy, one could argue that it was founded on an extension of one of the oldest elements of direct forms of democracy, acclamation, the shouts and cries accompanied by hand gestures and flag waving, that were at the core of both the liturgical power (Heron 2018) of the Christian church and the mass identifications of authoritarian and direct democracies. The acclamations of the public assembly, which had been displaced by the kind of acclamation produced by the corporate mass media, was now renewed, not least by the Trump campaign itself, in tandem with the likes, posts and "friending" of social media. The latter, which had been the basis of the business model of social media platforms in their use of "digital marketing," found its way into the marketing of political candidates. In so far as both populist politics and social media posts are versions of acclamatory will and affect, they share a previously unacknowledged affinity. While the Trump campaign exemplified the links between the acclamations of the political rally and those of social media (Dean 2018), it is not without note that both parties in Italy's populist government of 2018 were adepts in social media mobilization, with Five Star beginning as a digital movement. The scandals (e.g. regarding Cambridge Analytica and the use of Facebook profiles) that have ensued are nothing more than surface ripples of a deeper break in the transformation of the form of political acclamation that has provided legitimation within liberal democracies. Political acclamation has 
gone viral. It has jumped not only platforms, but also forms of media, and kinds of social and political collectivity.

It is remarkable that the shift in liberal-democratic politics is articulated in a similar fashion to the rollback phase of neoliberalism of the 1980s. De-regulation occurs in relation to environmental and financial areas (on the latter, witness the fate of Dodd-Frank). There is the abandonment of international agreements that impose regulatory standards and frameworks, e.g. the Paris Accords on climate. For the first time in a quarter century, there is a disarticulation with globalism, manifest in the withdrawal or threatened withdrawal from international trade agreements and pacts, or the demand for renegotiation of their terms. Given the success of the left takeover of neoliberal forms of governmentality, the response is less a form of governmentality than an anti-governmentality, a search for a return to a pure and virtuous market or national economy, no longer tethered by governmental regulation. In an Executive Order of April 10, 2018, "welfare reform" has become equivalent to enforcing a requirement of work for those seeking assistance of any kind, thus strengthening the "purgatorial ethic" that has animated it (Boland and Griffin 2017). In the demand for a removal of those vestiges of the welfare state that distort human virtue and proper conduct, there are deep layers of differential treatment of populations according to race and place. Nevertheless, the governmentality of the activation machine may prove as dispensable in the Trump era as the Art Deco friezes of his first Manhattan building project.

One should not underestimate how attitudes and most importantly affects toward race, migration and Muslims, played significant role in the electoral behavior of white voters in the United States. However, two questions remain unanswered. The first concerns how such attitudes and affects are mobilized and manipulated today. Here the need for rethinking the formation of the public sphere 
and the role of social and digital media is apparent, as too is the need for asking hard questions about the nature of political identification and the form that political acclamation takes today. The assertion of the presence of a new sphere of political manipulability is something to be explained, rather than the explanation it often claims to be. If at the core of these political identifications are affects such as resentment and anger towards others, then how is that these resentments have become central to large numbers of people's political behavior? While we should not ignore the complex history of racial and ethnic domination and exclusion in formerly colonial powers and current imperial ones, the neoliberal erosion of the welfare state and its transformation into a sphere akin to purgatory for social welfare recipients intensifies the personal experience of precarity, the resentment of those who must have recourse to it, and the vilification of those who have no other option.

Contemporary neoliberalism is rogue in the sense that it has lost its identification with a unified political movement providing it some kind of legitimacy. Broadly, it first entered the public political domain in the guise of a conservatism during its "rollback" phase, and then turned to labor and social democratic parties during its "roll-out" or implementation phase. Today, a rogue neoliberalism belongs to no one side and attaches itself to diverse political and economic formations: fundamentalist Christians and diversity advocates, finance and real-estate capital, progressive liberals and conservative authoritarians, sovereign decisionism and the rule of law. Anti-bureaucratic advocacy for businesses, the belief in market-based solutions, even for climate change, the vociferous boosterism of entrepreneurship and innovation, and the mantra of individual responsibility and self-help, are shared across progressive and reactive neoliberalism. With a few noble exceptions, the left has dealt itself out of the political game or joined on the side of the progressivist neoliberalism. If there is a civil war, it is, like the conflict between various kinds of 
Catholics and Protestants four centuries ago, not a war between different religions but different confessions of the same religion. Neoliberalism, which sought an economic neutralization of the political through the reconstruction of the state and the public domain as a set of markets that have no other legitimacy than an economic one, has displaced the political onto the domain of affective identity and identification: diverse and inclusive, on the one hand, and supremacist and nativist, on the other. The opportunities for the expression and participation in such a form of politics have multiplied with the internet; the key mechanism of identification are the acclamations (and narcissistic self-acclamations) that define social media. Neoliberalism has become a series of rogue affects, of tribal identifications formed through the ordeals and tests that mark, tattoo, mold and dress bodies in the pleasures of the enterprise, paraded in its different paradigms by a series of families: the Trumps, the Obamas, the Macrons, the Kardashians.

The present moment is crucial for the humanities and social sciences, undergoing their own transformations that have reconstructed the university space of research and teaching as one of competition and performance. They have the tools, the methods, the heritage and the historical sense to make the present intelligible. However, they are hampered by an inherited and now quite dominant critical traditions that have, among other things, reduced the political to a debate over forms of governance, displayed and encouraged an analytical anti-statism orientation, and absolutely neglected the problem of the formation of publics through the acclamations, ceremonies, protocols and liturgies of politics and political communication. One of the ways out of these analytical shortcomings has, for the past few years at least, required the radical problematizations made available by first a political, and then, an economic theology (Leshem 2016). The fruit of this intellectual program remains to be seen. 


\section{$\underline{\text { References }}$}

Beck, Ulrich. 1992. Risk Society: Towards a New Modernity. Translated by Mark Ritter. London: Sage.

Boland, Tom, and Griffin, Ray. 2017. "The Purgatorial Ethic and the Spirit of Welfare.” Journal of Classical Sociology 18, no. 2: 87-103.

Brenner, Neil, Peck, Jamie and Theodore, Nik. 2010. "Variegated Neoliberalization: Geographies, Modalities, Pathways." Global Networks 10: 182-222.

Brown, Wendy. 2010. Walled Sovereignty, Waning States. New York: Zone Books.

Chozick, Amy. 2016 “Hillary Clinton Calls Many Trump Backers 'Deplorables,' and G.O.P. Pounces." New York Times, September 10.

Dean, Mitchell. 1995. "Governing the Unemployed Self in an Active Society." Economy and Society 24, no. 4: 559-83.

Dean, Mitchell. 2002. "Liberal Government and Authoritarianism." Economy and Society 31, no. 1: $37-61$.

Dean, Mitchell. 2017. “Three Forms of Democratic Political Acclamation.” Telos 197: 9-32. 
Dean, Mitchell. 2018. "The Dark Arts Reach the Internet." TELOSscope, March 27. www.telospress.com/the-dark-arts-reach-the-internet/

Erlanger, Steven. 2018. "Fight Over Values Risks a 'European Civil War', Macron Says.” New York Times, April 17.

Fischer, Karin. 2009. “The Influence of Neoliberals in Chile Before, During and After Pinochet.” In The Road from Mont Pèlerin: The Making of the Neoliberal Thought Collective, edited by Philip Mirowski and Dieter Plehwe, 305-46. Cambridge, MA: Harvard University Press.

Foucault, Michel. 1988. "Social security,". In Politics, Philosophy, Culture: Interviews and Other Writings 1977-84, edited by Lawrence D. Kritzman, 159-77. New York: Routledge.

Foucault, Michel. 2007. Security, Territory, Population: Lectures at the Collège de France, 19771978. Translated by Graham Burchell. London: Palgrave Macmillan.

Foucault, Michel. 2008. The Birth of Biopolitics: Lectures at the Collège de France, 19781979. Translated by Graham Burchell. London: Palgrave Macmillan.

Giddens, Anthony. 1991. Modernity and Self-Identity: Self and Society in the Late Modern Age. Cambridge: Polity.

Giddens, Anthony. 1998. The Third Way: the Renewal of Social Democracy. Cambridge: Polity. 
Green, Joshua. 2017. Devil's Bargain: Steve Bannon, Donald Trump and the Storming of the Presidency. New York: Penguin Press.

Greenhouse, Linda. 2018. "The Supreme Court and the New Civil War," New York Times, April 26.

Hayek, Friedrich A. 1981. "Interview.” El Mercurio, April 12.

$\underline{\text { www.fahayek.org/index.php?option=com_content\&task=view\&id=121. }}$.

Heron, Nicholas. 2018. Liturgical Power: Between Economic and Political Theology. New York: Fordham University Press.

Hien, Josef. 2017. "The Religious Foundations of the European Crisis," Journal of Common Market Studies. DOI: 10.1111/jcms.12635.

Horowitz, Jason. 2018. “Italy’s Populists Offer Giuseppe Conte for Prime Minister, NYU Claim in Question,” New York Times, May 21.

Leshem, Dotan. 2016. The Origins of Neoliberalism: Modeling the Economy From Jesus to Foucault. New York: Columbia University Press.

Miller, James. 1993. The Passion of Michel Foucault. New York: Simon and Schuster.

Mirowski, Philip and Plehwe, Dieter eds. 2009. The Road from Mont Pèlerin: The Making of the Neoliberal Thought Collective. Cambridge, MA: Harvard University Press 
Peck, Jamie. 1998. "Workfare: a Geopolitical Etymology," Environment and Planning D, Society and Space 16: 133-161.

Schmitt, Carl. 2014. Dictatorship. Translated by Michael Hoezl and Graham Ward. Cambridge: Polity.

Schram, Sanford S. 2000. After Welfare: the Culture of Postindustrial Social Policy. New York: New York University Press.

Sennelart, Michel. 2007. “Course Context.” In Foucault, Security, Territory, Population, 365-401.

Ulmen, Gary L. 1985. "The sociology of the state: Carl Schmitt and Max Weber.” State, Culture, and Society 1, no. 2: 3-57.

Zamora, Daniel. 2017. “Alla Ricerca di una 'Governamentalità di Sinistra’ gli Ultimi Dieci Anni di Michel Foucault.” Materialismo Storico 2, no. 3: 319-45.

Zamora, Daniel and Behrent, Michael C. eds. 2016. Foucault and Neoliberalism. Cambridge: Polity Press. 